\title{
TWO NEW SPECIES OF PARTIDOMOMONIA COOK FROM SOUTH-EASTERN AUSTRALIA (ACARINA: MOMONIIDAE)
}

\author{
BY MARK S. HARVEY
}

Department of Invertebrate Survey, Museum of Victoria,

71 Victoria Crescent, Abbotsford, Victoria 3067, Australia

Present address: Western Australian Museum,

Francis Street, Perth, WA 6000, Australia

\begin{abstract}
Harvey, M.S., 1990. Two new species of Partidomomonia Cook from south-eastern Australia (Acarina: Momoniidae). Memoirs of the Museum of Victoria 50(2): 337-340.

Adult males of Partidomomonia blythi sp. nov. and an adult femaie of $P$. cabanandra sp. nov, are described from specimens collected in eastern Victoria. The generic diagnosis is amended, and a key to the three known species of the genus is presented.
\end{abstract}

\section{Introduction}

The water mite genus Partidomomonia Cook has a short history and only two specimens have been reported in the literature. The first was the male holotype of the type species, $P$. polyplacophora Cook, 1983 from New Zealand. The second, a deutonymph from Queensland, was described but not named by Cook (1986) and remains species inquirenda until adults are collected. The discovery of six further specimens representing two undescribed species from eastern Victoria in the collections of the Museum of Victoria, Melbourne (NMV) and the Canadian National Collection, Ottawa (CNC) is of interest, especially as one is a female, the first to be reported in the genus.

Methods follow Harvey (1987); abbreviations for the glandularia follow Harvey (1988).

\section{Partidomomonia Cook}

Partidomomonia Cook, 1983: 118. Type species: Partidomomonia polyplacophora Cook, 1983, by original designation.

Diagnosis. Dorsal shield divided into a number of platelets. Three pairs of genital acetabula, lying free in gonopore in males, and on separate lateral sclerites in gonopore in females.

Remarks. The discovery of the female of $P$. cabanandra described below, allows expansion of the generic diagnosis given by Cook (1983), which was based on male characters only, and reassessment of the generic affinities of Partidomomonia. Species of six momoniid genera have the genital acetabula of both sexes lying within the gonopore: Momonia Halbert, Momoniella K. Viets, Neomomonia Cook, Notomomonia Cook, Partidomomonia Cook and Momonides Lundblad. In males of the remaining three momoniid genera (Stygomomonia Szalay, Xenomomonia Orghidan, Gruia, Georgesco and Bayés and Momonisia Petrova) the acetabula lie in the ventral shield. [The descriptions of Cladomomonia Orghidan and Gruia given by Orghidan and Gruia $(1980,1983)$, conclusively show that the genus is not a momoniid as the type species lack the characteristic leg I typical of the family.] Partidomomonia clearly differs from the other five genera with acetabula of both sexes in the gonopore by the nature of the dorsal shield which is divided into a number of platelets, and on the basis of current knowledge does not appear to possess particularly close affinities to any of these genera.

\section{Key to adults of Partidomomonia}

1. Dorsal shield less than $450 \mu \mathrm{m}$ in length, $1.47-1.66 \times$ longer than

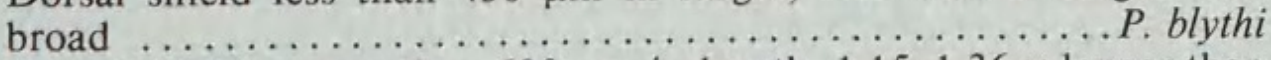
Dorsal shield greater than $600 \mu \mathrm{m}$ in length, $1.15-1.36 \times$ longer than

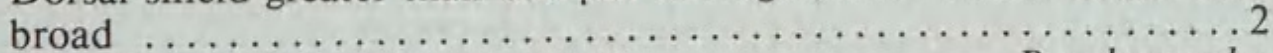

2. Tibia I much longer than tarsus I ............... cabanandra

- Tibia I approximately same length as tarsus I ....P. polyplacophora 
Partidomomonia blythi sp. nov.

Figures 1-6

Types. Holotype male, Thomson River at ThomsonJordan Divide Road, Victoria, 12 Mar 1987, R. Marchant (NMV K866).

Paratypes: Victoria: 1 male, same data except 12 Dec 1985, from frozen core, 10-20 cm level (NMV K867); 1 male, same data except 9 Mar 1980, staff of Biological Survey Department (NMV K868); 1 male, same data except Mar 1981 (NMV K869); 1 male, same data except 9 Mar 1979 (CNC).
Diagnosis. Dorsal shield relatively narrow, dorsal shield less than $450 \mu \mathrm{m}$ in length. Tibia I only slightly longer than tarsus I. Glandularium associated with $\mathrm{dg} 5$ absent.

Description. Adult male: Dorsal and ventral shields present. Dorsal shield (Fig. 1) divided into many close-fitting platelets (the irregular intersection of the medial platelets shown in Fig. 1 is not typical of the species); with postocularia, 3 pairs of dorsoglandularia, and 5 pairs of setae that lack associated glands $(\operatorname{dg} 3-5, \lg 2,5)$; dorsal
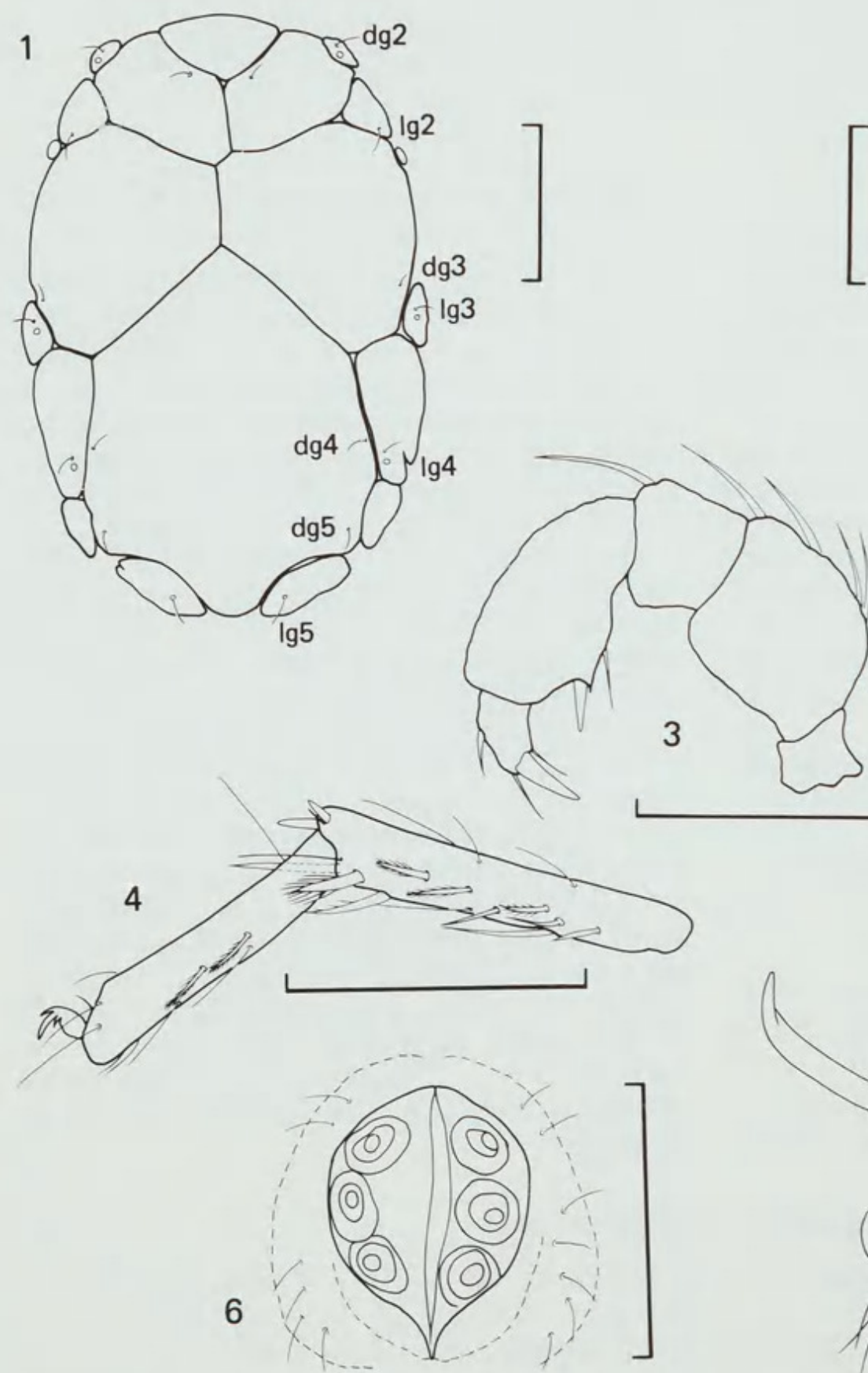

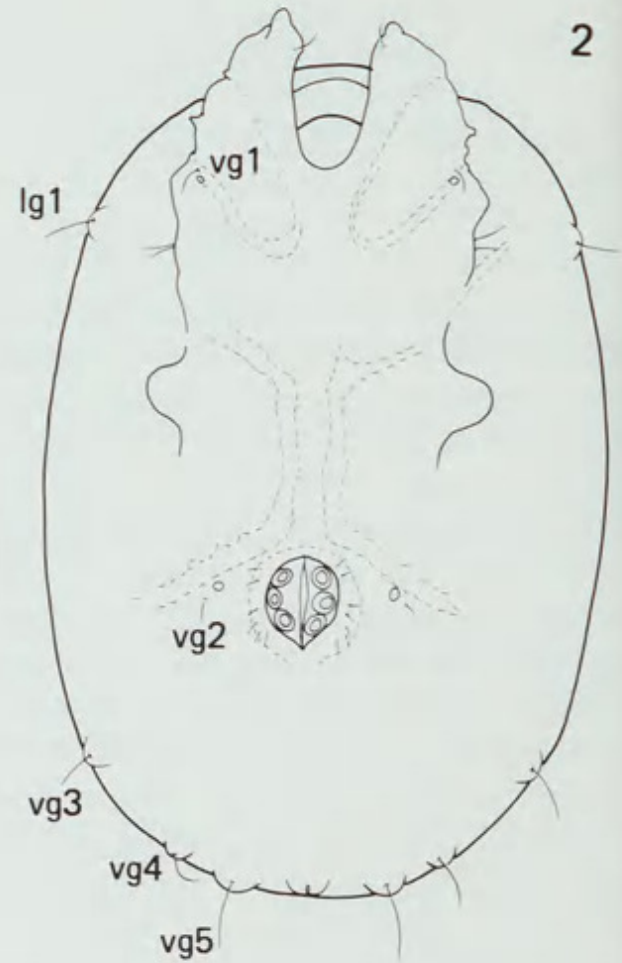

2

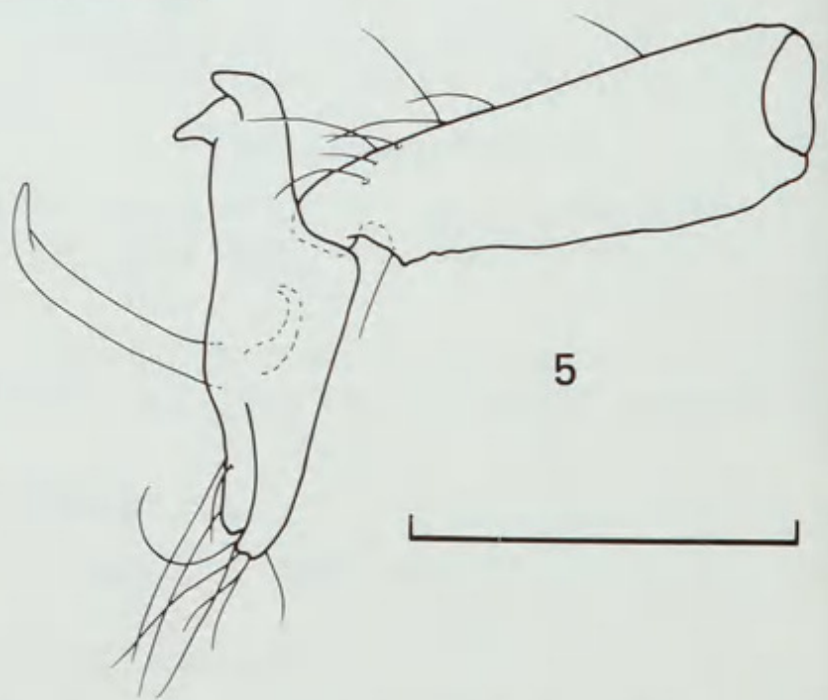

Figures 1-6. Partidomomonia blythi sp. nov., holotype male. Fig. 1, dorsal shield; fig. 2, ventral shield; fig. 3, right pedipalp; fig. 4, tibia and tarsus of left leg IV; fig. 5, tibia and tarsus of left leg I; fig. 6, genital field. Scale lines, $100 \mu \mathrm{m}$; except figs $3,6,50 \mu \mathrm{m}$. 
shield $1.47-1.66 \times$ longer than broad. Ventral shield (Fig. 2) entire; anterior coxae projecting beyond idiosoma; suture lines between coxae poorly defined; suture lines between coxae I absent; foramina of legs IV covered by large condyles; capitular bay rounded; with 7 pairs of glandularia (dg1, $\lg 1, \operatorname{vg} 1-5)$; dg1 on anterolateral margin (not visible in ventral view); vg1 situated at junction of coxae II and III; vg3-5 set in low tubercles on posterior margin; anus situated at posterior margin of ventral shield. Genital field (Fig. 6) with 3 pairs of acetabula situated within gonopore, not on separate sclerites; posterior margin pointed; surrounded by 6-7 pairs of small setae. Pedipalp (Fig. 3) not uncate; tibia with 1 large ventral seta on tubercle and 1 smaller ventral seta; tarsus with 1 large distal setae, and several smaller setae; all setae acumi-

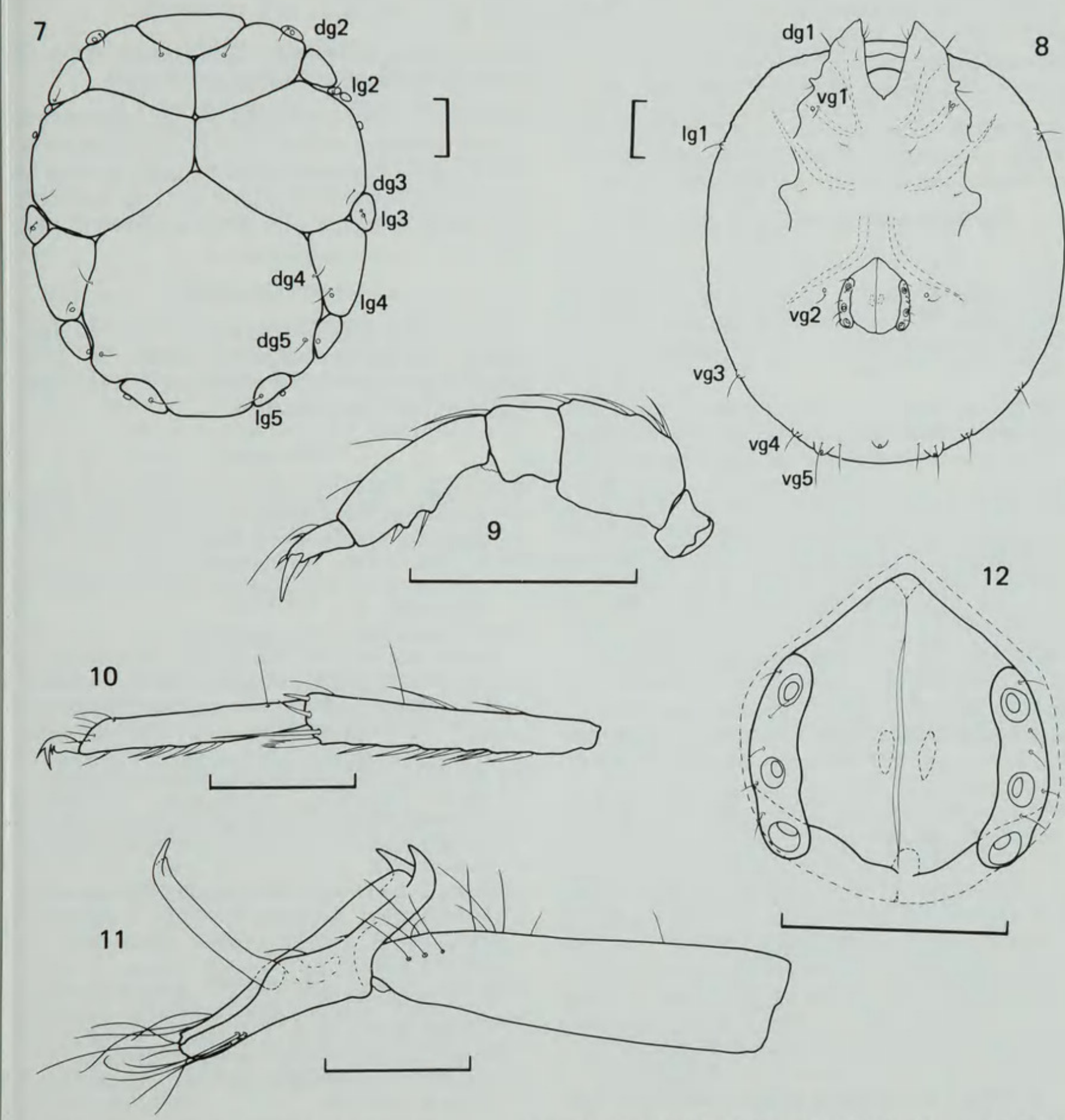

Figures 7-12. Partidomomonia cabanandra sp. nov., holotype female. Fig. 7, dorsal shield; fig. 8 ventral shield; fig. 9, right pedipalp; fig. 10, tibia and tarsus of left leg IV; fig. 11, tibia and tarsus of left leg I; fig. 12, genital field. Scale lines, $100 \mu \mathrm{m}$. 
nate. Legs (Figs. 4, 5): tarsus I with proximodorsal extension; distal portion of tarsus I bifurcate; claw enlarged, proximally directed; tibia I greatly enlarged, tubular, slightly longer than tarsus I; without swimming setae.

Dimensions $(\mu \mathrm{m})$ : Dorsal shield 390416/243-281; ventral shield 411-442/262-306. Capitulum length 48-65; chelicera length 7175. Genital field 49-55/37-41. Pedipalp: trochanter $15-16$, femur 38-41, genu 21-25, tibia $46-49$, tarsus $28-29$. Leg I: trochanter 32-38, basifemur 48-56, telofemur 64-67, genu 58-62, tibia $138-153$, tarsus 126-130. Leg IV: trochanter 59 , basifemur 63-65, telofemur 69-72, genu 88-98, tibia 129-138, tarsus 114-119.

Etymology. This species is named for John Blyth, coordinator of much of the early ecological work conducted on the Thomson River.

\section{Partidomomonia cabanandra sp. nov.}

Figure 7-12

Type. Holotype female, Bowen Creek, $2 \mathrm{~km}$ SW of Cabanandra, Victoria, interstitial sample, 9 Apr 1985 , D.R. Cook, M.S. Harvey and A.J. Boulton (NMV K870).

Diagnosis. Dorsal shield somewhat round, 698 $\mu \mathrm{m}$ in length. Tibia I much longer than tarsus I. Glandularium associated with dg5 present.

Description. Adult female: Dorsal and ventral shields present. Dorsal shield (Fig. 7) divided into many close-fitting platelets; with postocularia, 4 pairs of dorsoglandularia, and 4 pairs of setae that lack associated glands $(\mathrm{dg} 3-4, \lg 2,5)$; dorsal shield 1.15 times longer than broad. Ventral shield (Fig. 8) entire; anterior coxae projecting beyond idiosoma; suture lines between coxae poorly defined; suture lines between coxae I absent; foramina of legs IV covered by large ventral lobes; capitular bay rounded; with 7 pairs of glandularia (dgl, $\lg 1, \operatorname{vg} 1-5)$; dg1 situated on anterolateral margin (not visible in ventral view); vgl situated at junction of coxae II and III; vg3-5 set in low tubercles on posterior margin; anus removed from posterior margin of ventral shield. Genital field (Fig. 12) with 3 pairs of acetabula situated on separate lateral sclerites within gonopore; each sclerite with 5 small setae. Pedipalp (Fig. 9) not uncate; tibia with 1 large ventral seta on tubercle and 1 smaller ventral seta; tarsus with 1 large distal setae and several smaller setae; all setae acuminate. Legs (Figs. 10, $11)$ : tarsus I with proximodorsal extension; dis- tal portion of tarsus I bifurcate; claw enlarged, proximally directed; tibia I greatly enlarged, tubular, much longer than tarsus I; without swimming setae.

Dimensions $(\mu \mathrm{m})$ : Dorsal shield 698/607; ventral shield 731/632. Capitulum length 90; chelicera length 119. Genital field 136/133. Pedipalp: trochanter 25 , femur 62 , genu 38 , tibia 78 , tarsus 46 . Leg I: trochanter 47 , basifemur 83 , telofemur 111, genu 102, tibia 292, tarsus 212. Leg IV: trochanter 92, basifemur 114, telofemur 109 , genu 147, tibia 199, tarsus 106.

Etymology. The specific epithet is a noun in apposition taken from the type locality.

Remarks. This relatively large, somewhat rounded species differs from $P$. polyplacophora and $P$. blythi in several respects, most notably in the relative lengths of the tibia and tarsus of leg I, and in the presence of a gland associated with $\operatorname{dg} 5$.

\section{Acknowledgments}

This work was funded by a grant from the Australian Biological Resources Study. Dr I.M. Smith kindly returned a collection of Thomson River mites for my studies.

\section{References}

Cook, D.R., 1983. Rheophilic and hyporheic water mites from New Zealand. Contributions of the American Entomological Institute 21 (2): 1-224.

Cook, D.R., 1986. Water mites from Australia. Memoirs of the American Entomological Institute 40: $1-568$.

Harvey, M.S., 1987. New and little-known species of the water mite genera Tartarothyas, Pseudohydryphantes and Cyclohydryphantes from Australia (Chelicerata: Actinedida: Hydryphantidae). Memoirs of the Museum of Victoria 48: 107122.

Harvey, M.S., 1988. Three new unusual water mites from Australia (Chelicerata: Acarina: Hydryphantidae, Hygrobatidae and Athienemanniidae). Memoirs of the Museum of Victoria 49: 355-361.

Orghidan, T. and Gruia, M., 1980. Diagnose de trois hydrachnelles nouveaux de Cuba. Travaux de l'Institute de Spéologie "Émile Racovitza" 19: 143-146.

Orghidan, T. and Gruia, M., 1983. Sur trois espèces d'Hydrachnellae de Cuba appartenant au genre Cladomomonia Orgh. \& Gruia et au sous-genre Crocokongsbergia Orgh. \& Gruia. Résultats des Expéditions Biospélogiques Cubano-Roumaines à Cuba 4: 167-179. 


\section{$2 \mathrm{BHL}$ Biodiversity Heritage Library}

1990. "Two new species of Partidomomonia Cook from south-eastern Australia (Acarina: Momoniidae)." Memoirs of the Museum of Victoria 50, 337-340.

View This Item Online: https://www.biodiversitylibrary.org/item/122636

Permalink: https://www.biodiversitylibrary.org/partpdf/50245

\section{Holding Institution}

Museums Victoria

\section{Sponsored by}

Atlas of Living Australia

\section{Copyright \& Reuse}

Copyright Status: Permissions to digitize granted by rights holder.

This document was created from content at the Biodiversity Heritage Library, the world's largest open access digital library for biodiversity literature and archives. Visit BHL at https://www.biodiversitylibrary.org. 